\title{
RAPD and ISSR markers in the evaluation of genetic divergence among accessions of elephant grass
}

\author{
R.S.N de Lima ${ }^{1}$, R.F. Daher ${ }^{1}$, L.S.A. Gonçalves' ${ }^{1}$, D.A. Rossi ${ }^{1}$, \\ A.T. do Amaral Júnior ${ }^{1}$, M.G. Pereira ${ }^{1}$ and F.J.S. Lédo ${ }^{2}$ \\ ${ }^{1}$ Universidade Estadual do Norte Fluminense Darcy Ribeiro, \\ Campos dos Goytacazes, RJ, Brasil \\ ${ }^{2}$ Empresa Brasileira de Pesquisa Agropecuária, \\ Centro Nacional de Pesquisa de Gado de Leite, Juiz de Fora, MG, Brasil \\ Corresponding author: L.S.A. Gonçalves \\ E-mail: lsagrural@yahoo.com.br
}

Genet. Mol. Res. 10 (3): 1304-1313 (2011)

Received October 14, 2010

Accepted December 8, 2010

Published July 5, 2011

DOI 10.4238/vol10-3gmr1107

\begin{abstract}
Considering the expected genetic variability of elephant grass (Pennisetum purpureum), due to its cultivation in different continents, we characterized and estimated the genetic divergences between 46 accessions of elephant grass with different edaphoclimatic adaptations, using RAPD and ISSR markers. We evaluated, comparatively, the consistency of the information achieved with these markers. Twenty-six RAPD and 25 ISSR primers were employed. The RAPD markers produced 185 bands, $72 \%$ of which were polymorphic, with a mean of 5.11 polymorphic bands per primer. The 25 ISSR starters produced 216 bands; $76 \%$ were polymorphic, with a mean of 6.56 polymorphic bands per primer. The correlation between the genetic distances achieved by the RAPD and ISSR markers was 0.76 , which is highly significant by the Mantel test. Based on UPGMA grouping, considering the point of sudden change, five and six groups were formed for the data from the RAPD and ISSR markers, respectively.
\end{abstract}


These markers provided partially concordant groups, indicating that these techniques can provide consistent information and consequently could be used in studies of genetic diversity among accessions.

Key words: Pennisetum purpureum Schum.; RAPD and ISSR markers; Genetic variability

\section{INTRODUCTION}

Elephant grass (Pennisetum purpureum Schum.) comes from West Africa and is considered to be one of the major forage plants in the tropics and subtropics, due to its high yield, good forage quality and application versatility (Daher et al., 2002; Bhandari et al., 2006; Pereira et al., 2008; Harris et al., 2009; Struwig et al., 2009). Besides, this grass has potential to produce biofuels, such as charcoal, alcohol, and methane (Sanderson et al., 1996; Anderson et al., 2008; Strezov et al., 2008; Jakob et al., 2009; Morais et al., 2009; Lee et al., 2010).

This grass is an allotetraploid $(2 \mathrm{n}=4 \mathrm{x}=28)$ of free pollination, and the large quantity of cultivars and genetic diversity result from its natural crossings (Bhandari et al., 2006). Therefore, the conservation of these materials in germplasm is very important for genetic breeding and to guard against unforeseen threats in agricultural production, such as epiphytes and climate change (Gepts, 2006; Gonçalves et al., 2008; Sudré et al., 2010).

In such context, active germplasm banks of elephant grass are maintained in many countries of the world, including South Africa, Brazil, Puerto Rico, the United States of America, Australia, China, Pakistan, and India (Bhandari et al., 2006). However, the accessions maintained in germplasm banks need characterization and evaluation, since, besides providing better knowledge about the germplasm available, which is essential for more intensive use in further stages, characterization and evaluation also allow the identification of duplicate accessions, settlement of nuclear collections and the identification of the modes of reproduction prevailing in the accessions, as well as of the occurrence or absence of intrinsic variability in individual accessions.

The characterization and evaluation may be based on agronomic, morphological, biochemical, molecular, and other information (Mohammadi and Prasanna, 2003; Gonçalves et al., 2009). However, molecular markers present more advantages because they reveal genetic differences with more details without the interference caused by environmental effects, providing fast results in the discrimination of the present diversity (Arif et al., 2010; Leal et al., 2010; Oliveira et al., 2010).

Some studies using molecular markers have been carried out in elephant grass aiming at achieving better understanding about diversity and kinship. RFLP (restriction fragment length polymorphism; Smith et al., 1993), RAPD (random amplified polymorphic DNA; Smith et al., 1993; Daher et al., 2002; Lowe et al., 2003; Passos et al., 2005; Pereira et al., 2008; Babu et al., 2009), AFLP (amplified fragment length polymorphism; Harris et al., 2009), and ISSR (inter-simple sequence repeats; Babu et al., 2009) are examples of such use.

The present study aimed at: i) characterizing and estimating the genetic diversity among 46 accessions of elephant grass from six countries, including forms which adapt to the edaphoclimatic conditions of Central and South America, using RAPD and ISSR markers, and ii) evaluating, comparatively, the congruence of the information achieved with the use of RAPD and ISSR markers. 


\section{MATERIAL AND METHODS}

\section{Plant material and DNA extraction}

Forty-six clones of elephant grass (Table 1) were used. The total cell DNA was extracted from young leaves using a commercial kit (Plant Genomic DNA ${ }^{\circledR}$ ). After the DNA extraction, DNA quantification was performed on agarose gels at $1.0 \%$. The High DNA Mass Ladder (Invitrogen, USA) marker was used. The gel was stained with a mixture of 6X Blue Juice ( $0.4 \mathrm{~mL} 0.5 \mathrm{M}$ 10X TAE; $0.2 \mathrm{~mL} 10 \% \mathrm{SDS} ; 0.2 \mathrm{~mL}$ bromophenol blue; $7.0 \mathrm{~mL}$ glycerol; $1.7 \mathrm{~mL}$ sterile water) with $5 \mathrm{X}$ GelRed $(1 \mu \mathrm{L} 10,000 \mathrm{X}$ GelRed in $0.5 \mathrm{~mL}$ dimethyl sulfoxide (DMSO); $2 \mathrm{~mL}$ ultrapure water), in a 1:1 proportion. The image was revealed using the resources of the MiniBis Pro photo-documentation system.

\begin{tabular}{|c|c|c|c|c|c|}
\hline Identification & Common name & Provenance & Identification & Common name & Provenance \\
\hline BGCE01 & Merker S.E.A. & UFRRJ, km 47, Brazil & BGCE24 & Costa Rica & Costa Rica \\
\hline BGCE02 & Merkeron Pinda & UFRRJ, km 47, Brazil & BGCE25 & Híbrido Gigante da Colômbia & Colombia \\
\hline BGCE03 & Cubano Pinda & UFRRJ, km 47, Brazil & BGCE26 & Elefante de Colômbia & Colombia \\
\hline BGCE04 & Merkeron Cubano de Pinda & Pindamonhangaba, SP, Brazil & BGCE27 & Guaçu/IZ.2 & Nova Odessa, SP, Brazil \\
\hline BGCE05 & Merkeron Comum & UFRRJ, km 47, Brazil & BGCE28 & Napier Volta Grande & UFRRJ, km 47, Brazil \\
\hline BGCE06 & P-241-Piracicaba No. 9 & Embrapa, CNPGL, Brazil & BGCE29 & IJ $7141 \mathrm{cv}$ EMPASC 306 & Embrapa, CNPGL, Brazil \\
\hline BGCE07 & Elefante Híbrido 534-A & UFV, Brazil & BGCE30 & Elefante de Pinda & Colombia \\
\hline BGCE08 & Mole de Volta Grande & Volta Grande, SP, Brazil & BGCE31 & Merker 86, México & Colombia \\
\hline BGCE09 & Vruckwona & Embrapa, CNPGL, Brazil & BGCE32 & Três Rios & Nova Odessa, SP, Brazil \\
\hline BGCE10 & Napier & UFV, Brazil & BGCE33 & Cameron, Piracicaba & UFRRJ, km 47, Brazil \\
\hline BGCE11 & Mineiro & Pedro Leopoldo, MG, Brazil & BGCE34 & IAC, Campinas & UFRRJ, km 47, Brazil \\
\hline BGCE12 & Africano & UFRRJ, km 47, Brazil & BGCE35 & Duro de Volta Grande Elefante & UFRRJ, km 47, Brazil \\
\hline BGCE13 & Taiwan A-148 & UFRRJ, km 47, Brazil & BGCE36 & Cachoeiro Itapemirim & UFRRJ, km 47, Brazil \\
\hline BGCE14 & Taiwan A-144 & UFRRJ, km 47, Brazil & BGCE37 & Gigante de Pinda & Pindamonhangaba, SP, Brazil \\
\hline BGCE15 & Capim - Cana D’África & EMCAPA, ES, Brazil & BGCE38 & Porto Rico & UFRRJ, km 47, Brazil \\
\hline BGCE16 & King Grass & Cuba & BGCE39 & Pusa Gigante Napier & India \\
\hline BGCE17 & Merker Santa Rita & UFRRJ, km 47, Brazil & BGCE40 & Pusa Napier No. 1 & India \\
\hline BGCE18 & Gramafante & RS, Brazil & BGCE41 & Cuba-116 & Cuba \\
\hline BGCE19 & Napier Goiano & GO, Brazil & BGCE42 & Taiwan A-146 & UFRRJ, km 47, Brazil \\
\hline BGCE20 & Merker & Limpa, MG, Brazil & BGCE43 & Pasto Panamá & Panama \\
\hline BGCE21 & Turrialba & UFRRJ, km 47, Brazil & BGCE44 & Vrukwonal & Embrapa, CNPGL, Brazil \\
\hline BGCE22 & Cameroon & Embrapa, CNPGL, Brazil & BGCE45 & Albano & Colombia \\
\hline BGCE23 & Roxo & Lavras, MG, Brazil & BGCE46 & Napier S.E.A. & UFRRJ, km 47, Brazil \\
\hline
\end{tabular}

\section{RAPD and ISSR amplification}

To achieve RAPD and ISSR fragments, first the selection of primers was performed and 26 and 25 primers were selected, respectively (Tables 2 and 3). The amplification reaction was carried out according to the protocol proposed by Williams et al. (1990), with some modification, for a final volume of $20 \mu \mathrm{L}$. The reaction contained the following concentration: 2 $\mu \mathrm{L} 10 \mathrm{X}$ buffer (500 mM KCl, $100 \mathrm{mM}$ Tris-HCL, pH 8.4), $2 \mu \mathrm{L} 25 \mathrm{mM} \mathrm{MgCl}, 1.6 \mu \mathrm{L} 2 \mathrm{mM}$ dNTPs, $1 \mu \mathrm{L}$ DMSO, $1.8 \mu \mathrm{L} 0.5 \mathrm{mM}$ primer, $0.12 \mu \mathrm{L} 5 \mathrm{U}$ Taq DNA polymerase and $2 \mu \mathrm{L} 5 \mathrm{ng}$ genomic DNA. The final volume was completed with ultrapure water. The polymerase chain reactions (PCR) for the RAPD marker were conducted as follows: 4 min at $94^{\circ} \mathrm{C}$, continuing for 45 cycles $\left(94^{\circ} \mathrm{C}\right.$ for $1 \mathrm{~min}, 35^{\circ} \mathrm{C}$ for $1 \mathrm{~min}$ and $72^{\circ} \mathrm{C}$ for $3 \mathrm{~min}$ ), and a final extension at $72^{\circ} \mathrm{C}$ for $7 \mathrm{~min}$. In relation to the ISSR markers, the PCRs followed this routine: $3 \mathrm{~min}$ at $94^{\circ} \mathrm{C}$, 
continuing for 42 cycles $\left[94^{\circ} \mathrm{C}\right.$ for $1 \mathrm{~min}, 30-57^{\circ} \mathrm{C}$ for $1 \mathrm{~min}$ (depending on the starter used) and $72^{\circ} \mathrm{C}$ for $3 \mathrm{~min}$ ], and a final extension at $72^{\circ} \mathrm{C}$ for $7 \mathrm{~min}$.

The products of the amplifications were separated on $1.5 \%$ agarose gel. The $1-\mathrm{kb}$ DNA Ladder (Invitrogen) marker was used. The gel was stained with a mixture of 6X Blue Juice ( $0.4 \mathrm{~mL} 0.5 \mathrm{M}$ 10X TAE; $0.2 \mathrm{~mL} 10 \% \mathrm{SDS} ; 0.2 \mathrm{~mL}$ bromophenol blue; $7.0 \mathrm{~mL}$ glycerol; $1.7 \mathrm{~mL}$ sterile water) with $5 \mathrm{X}$ GelRed $(1 \mu \mathrm{L} 10,000 \mathrm{X}$ GelRed in $0.5 \mathrm{~mL}$ DMSO; $2 \mathrm{~mL}$ ultrapure water), at a 1:1 proportion. The image was revealed by the resources of the MiniBis Pro photo-documentation system.

\section{Data analysis}

For the analysis of RAPD and ISSR markers, the gels revealed were visualized and, later, interpreted by the presence or absence of bands, with the generation of a binary matrix. To estimate the genetic distances between genotypes, the Jaccard similarity coefficient was used. Later, the Pearson correlation was carried out, with the use of the Mantel test (10,000 permutations), among the distance matrices of the RAPD and ISSR markers. The simplified representation of the genetic distances between the accessions was achieved by the UPGMA (unweighted pair-group method using arithmetic average) method and represented by a dendrogram. All the analyses were carried out using the $\mathrm{R}$ system software (http://www.r-project.org).

\section{RESULTS AND DISCUSSION}

\section{RAPD marker}

By RAPD analysis, each primer produced easily detectable bands with variable intensity, and nonspecific bands, which were discarded. The 26 primers used produced 185 bands (Table 2). Of these, 133 were polymorphic (71.89\%) and 52, monomorphic (28.11\%). The number of polymorphic bands varied from 2 to 8 , which occurred with the OPC-04 and OPAA-20 primers, respectively. The level of polymorphism verified in the present study is in accordance with those achieved by Pereira et al. (2008) and Passos et al. (2005), but lower than those achieved by Babu et al. (2009), who evaluated 30 accessions of elephant grass and detected $87.84 \%$ polymorphism.

The analysis of the frequency distribution of the dissimilarity of 1035 combinations for the pairs of the 46 accessions of elephant grass revealed that the distribution was uniform, ranging from 0.10 to 0.47 with an average of $0.33( \pm 0.04)$, which is higher than that achieved by Pereira et al. (2008) and Passos et al. (2005), who verified an average distance of 0.21 and 0.25 , respectively (Figure 1). The classes $0.30-0.35$ and $0.35-0.40$ revealed the highest frequencies, with magnitudes of 33.62 and 24.83 , respectively. It is possible, therefore, to infer that RAPD markers were efficient in detecting the genetic variability among the accessions evaluated in the present study. The accessions BGCE09 (Vruckwona) and BGCE30 (Elefante de Pinda) were the most genetically distant, with the value of 0.47 , while BGCE34 (IACCampinas) and BGCE44 (Vruckwona1) were the closest (0.11).

Five groups were formed by a cut at the distance of 0.31 , considering the most abrupt turning point in the dendogram (Figure 2). Groups I and II gathered $71.74 \%$ of the accessions. 


\begin{tabular}{|c|c|c|c|}
\hline \multirow[t]{2}{*}{ Primers } & \multicolumn{2}{|c|}{ Bands } & \multirow[t]{2}{*}{ Total } \\
\hline & Monomorphic & Polymorphic & \\
\hline OPA-2 & 4 & 5 & 9 \\
\hline OPA-8 & 1 & 4 & 5 \\
\hline OPA-9 & 2 & 6 & 8 \\
\hline OPAA-11 & 3 & 6 & 9 \\
\hline OPAA-16 & 3 & 3 & 6 \\
\hline OPAA-20 & 2 & 8 & 10 \\
\hline OPAB-2 & 2 & 5 & 7 \\
\hline OPAB-4 & 1 & 6 & 7 \\
\hline OPAB-6 & 2 & 6 & 8 \\
\hline OPAB-9 & 1 & 6 & 7 \\
\hline OPAC-12 & 1 & 7 & 8 \\
\hline OPAC-17 & 2 & 6 & 8 \\
\hline OPAD-11 & 1 & 8 & 9 \\
\hline OPAE-11 & 2 & 8 & 10 \\
\hline OPAE-18 & 3 & 3 & 6 \\
\hline OPAW-15 & 1 & 5 & 6 \\
\hline OPAW-9 & 2 & 3 & 5 \\
\hline OPB-17 & 2 & 3 & 5 \\
\hline OPC-11 & 1 & 7 & 8 \\
\hline OPC-12 & 2 & 3 & 5 \\
\hline OPC-16 & 3 & 3 & 6 \\
\hline OPC-4 & 4 & 2 & 6 \\
\hline OPD-13 & 2 & 4 & 6 \\
\hline OPD-20 & 1 & 6 & 7 \\
\hline OPN-15 & 2 & 4 & 6 \\
\hline OPN-5 & 2 & 6 & 8 \\
\hline Total & 52 & 133 & 185 \\
\hline
\end{tabular}
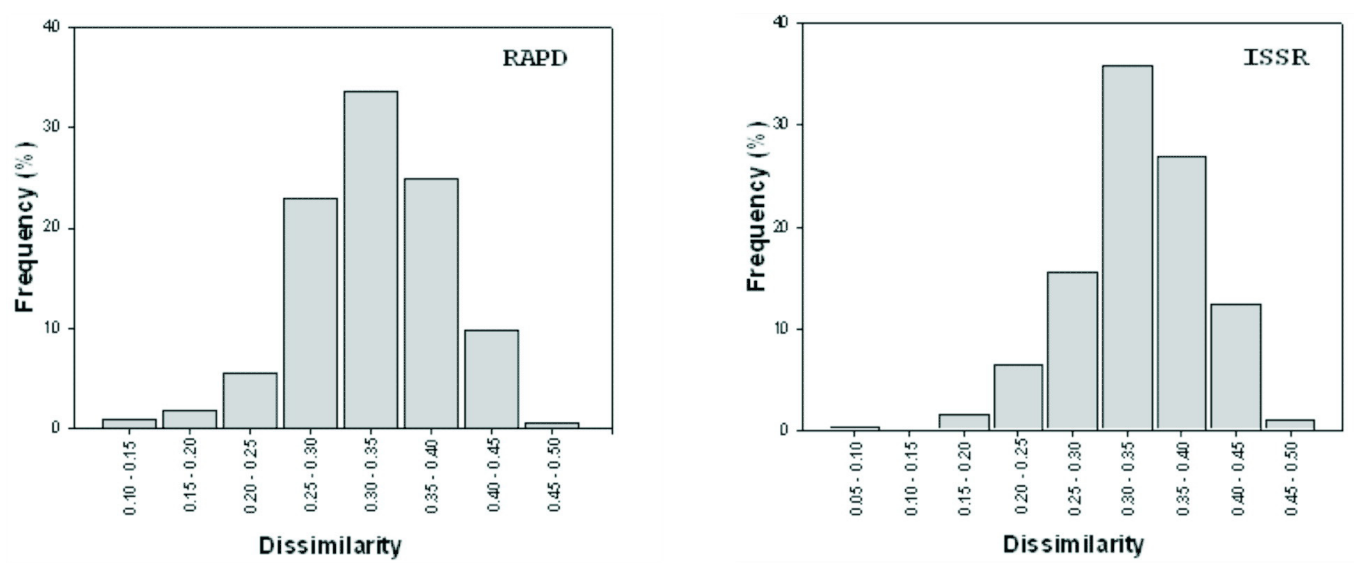

Figure 1. Frequency distribution of the dissimilarity based on RAPD and ISSR markers among the 46 accessions of elephant grass.

Group I comprised 17 accessions, and Group II, 16 accessions. Groups III, IV and V were formed by 1, 2 and 10 accessions, respectively (Figure 2). The accessions BGCE9, BGCE34 and BGCE15 (Vruckwona, IAC-Campinas and Capim Cana d' África, respectively) allocated in Group II were also allocated in the same group in the results of Passos et al. (2005) and Pereira et al. (2008). The accessions BGCE10 and BGCE11 (Napier and Mineiro, respec- 
tively) were gathered in Group I, which also occurred with the results achieved by Daher et al. (1997a) when using enzyme standards; by Daher et al. (1997b) and Shimoya et al. (2002), using morphoagronomic descriptors, and by Passos et al. (2005) and Pereira et al. (2008).

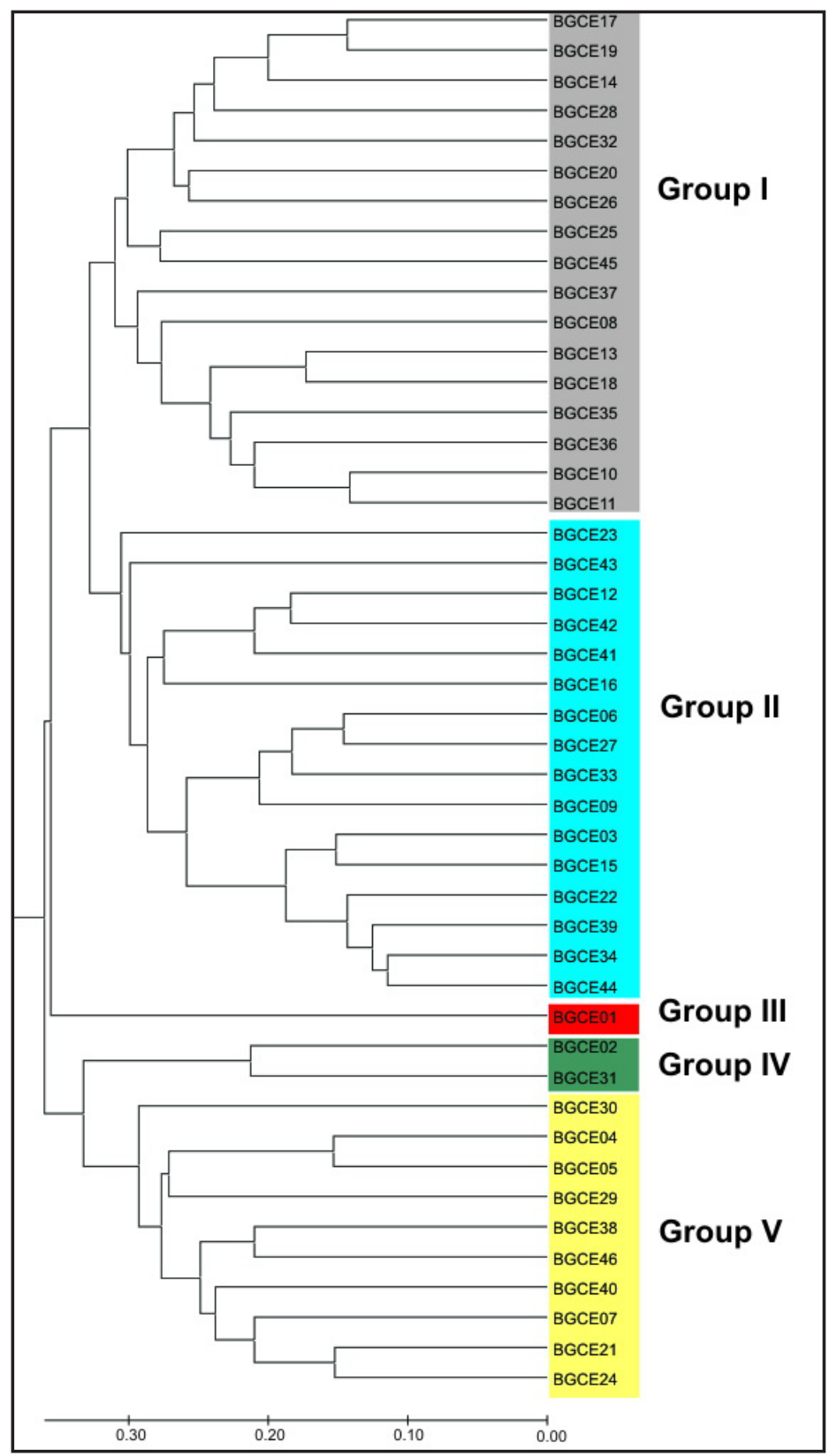

Figure 2. Dendrogram of genetic divergence among 46 accessions of elephant grass using the Jaccard coefficient based on the UPGMA algorithm from RAPD data. 


\section{ISSR marker}

From the analysis of the ISSR markers, the 25 primers used produced 216 bands clearly visualized on the gels. Of these, 164 were polymorphic (75.93\%) and 52, monomorphic $(24.07 \%)$ (Table 3$)$. The starter $(\mathrm{AG})_{8} \mathrm{CTA}$ was the most informative, providing the amplification of 11 fragments, while $(\mathrm{GT})_{6} \mathrm{CC}$ presented the smallest quantity of polymorphic fragments, a total of only two.

\begin{tabular}{|c|c|c|c|}
\hline \multirow[t]{2}{*}{ Primers } & \multicolumn{2}{|c|}{ Bands } & \multirow[t]{2}{*}{ Total } \\
\hline & Monomorphic & Polymorphic & \\
\hline$(\mathrm{GAGA})_{3} \mathrm{CC}$ & 1 & 7 & 8 \\
\hline$(\mathrm{GT})_{6} \mathrm{CC}$ & 3 & 2 & 5 \\
\hline$(\mathrm{AC})_{3} \mathrm{GC}$ & 3 & 6 & 9 \\
\hline$(\mathrm{AC})_{8}^{3} \mathrm{CT}$ & 2 & 5 & 7 \\
\hline$(\mathrm{AC}){ }_{8}^{8} \mathrm{YG}$ & 4 & 6 & 10 \\
\hline$(\mathrm{GGAT})_{3} \mathrm{GA}$ & 4 & 4 & 8 \\
\hline$(\mathrm{GAA})_{6} \mathrm{AA}$ & 0 & 9 & 9 \\
\hline$(\mathrm{CT})_{\mathrm{g}} \mathrm{G}$ & 1 & 8 & 9 \\
\hline$(\mathrm{AC})_{8}^{8} \mathrm{~T}$ & 2 & 8 & 10 \\
\hline$(\mathrm{AG})_{8} \mathrm{YT}$ & 1 & 8 & 9 \\
\hline$(\mathrm{AG})_{8} \mathrm{YA}$ & 4 & 5 & 9 \\
\hline$(\mathrm{ATG})_{6}$ & 0 & 6 & 6 \\
\hline$(\mathrm{GACA})_{4}$ & 0 & 9 & 9 \\
\hline $\operatorname{DBD}(\mathrm{AC})_{7}$ & 3 & 5 & 8 \\
\hline$(\mathrm{GA})_{8} \mathrm{C}$ & 2 & 7 & 9 \\
\hline$(\mathrm{GA})_{8}^{8} \mathrm{~T}$ & 5 & 6 & 11 \\
\hline$(\mathrm{AC})_{8}^{8} \mathrm{C}$ & 2 & 7 & 9 \\
\hline$(\mathrm{ACT})_{6} \mathrm{~T}$ & 2 & 6 & 8 \\
\hline$(\mathrm{ACT}){ }_{6} \mathrm{C}$ & 2 & 8 & 10 \\
\hline$(\mathrm{ATG})_{6}^{6} \mathrm{G}$ & 2 & 5 & 7 \\
\hline $\mathrm{G}(\mathrm{CTA})_{6}$ & 2 & 4 & 6 \\
\hline$(\mathrm{GA})_{9} \mathrm{~T}^{6}$ & 0 & 10 & 10 \\
\hline$(\mathrm{GA}), \mathrm{AC}$ & 2 & 7 & 9 \\
\hline$(\mathrm{ACC})_{4} \mathrm{Y}$ & 5 & 5 & 10 \\
\hline$(\mathrm{AG})_{8} \mathrm{CTA}$ & 0 & 11 & 11 \\
\hline Total & 52 & 164 & 216 \\
\hline
\end{tabular}

The analysis of the frequency distribution of the dissimilarity revealed uniform distribution, ranging from 0.05 to 0.50 , with an average of $0.34( \pm 0.05)$, and the classes $0.30-0.35$ and 0.35-0.40 presented the highest frequency, with estimates of 35.84 and 26.96 , respectively (Figure 1). These results agree with those achieved with the RAPD markers, indicating that both markers were efficient in detecting the genetic similarity and dissimilarity among the accessions evaluated in the present study. BGCE12 (Africano) and BGCE30 (Elefante de Pinda) presented the highest values for the genetic distance (0.48) for the ISSR marker. The same accessions presented a genetic distance of 0.38 for the RAPD technique, while BGCE09 and BGCE30, the most divergent for these markers, revealed a genetic distance of 0.43 by the ISSR markers, corroborating the high genetic separation among these accessions. The accessions BGCE04 (Merkeron Cubano de Pinda) and BGCE05 (Merkeron Comum) were the most similar, with a genetic distance of 0.06 . They presented a distance of 0.15 by the RAPD marker, while BGCE34 and BGCE44, the most similar by the RAPD technique, revealed a genetic distance of 0.17 , corroborating the genetic proximity among them.

Six groups were formed based on a cut performed at a distance of 0.31 , consider- 
ing the most abrupt point of change in the dendrogram (Figure 3). Groups I and VI gathered $80.43 \%$ of the accessions; Group I comprised 18 accessions, and Group VI, 19 accessions. Groups II, III, IV, and V were formed by 6, 1, 1, and 1 accessions, respectively (Figure 3 ). The union of the accessions BGCE09, BGCE34 and BGCE15 in the same group (Group VI), and BGCE10 and BGCE11, in Group I, corroborates the results achieved by the RAPD marker, which indicates the validity of the use of both techniques for the accessions studied.

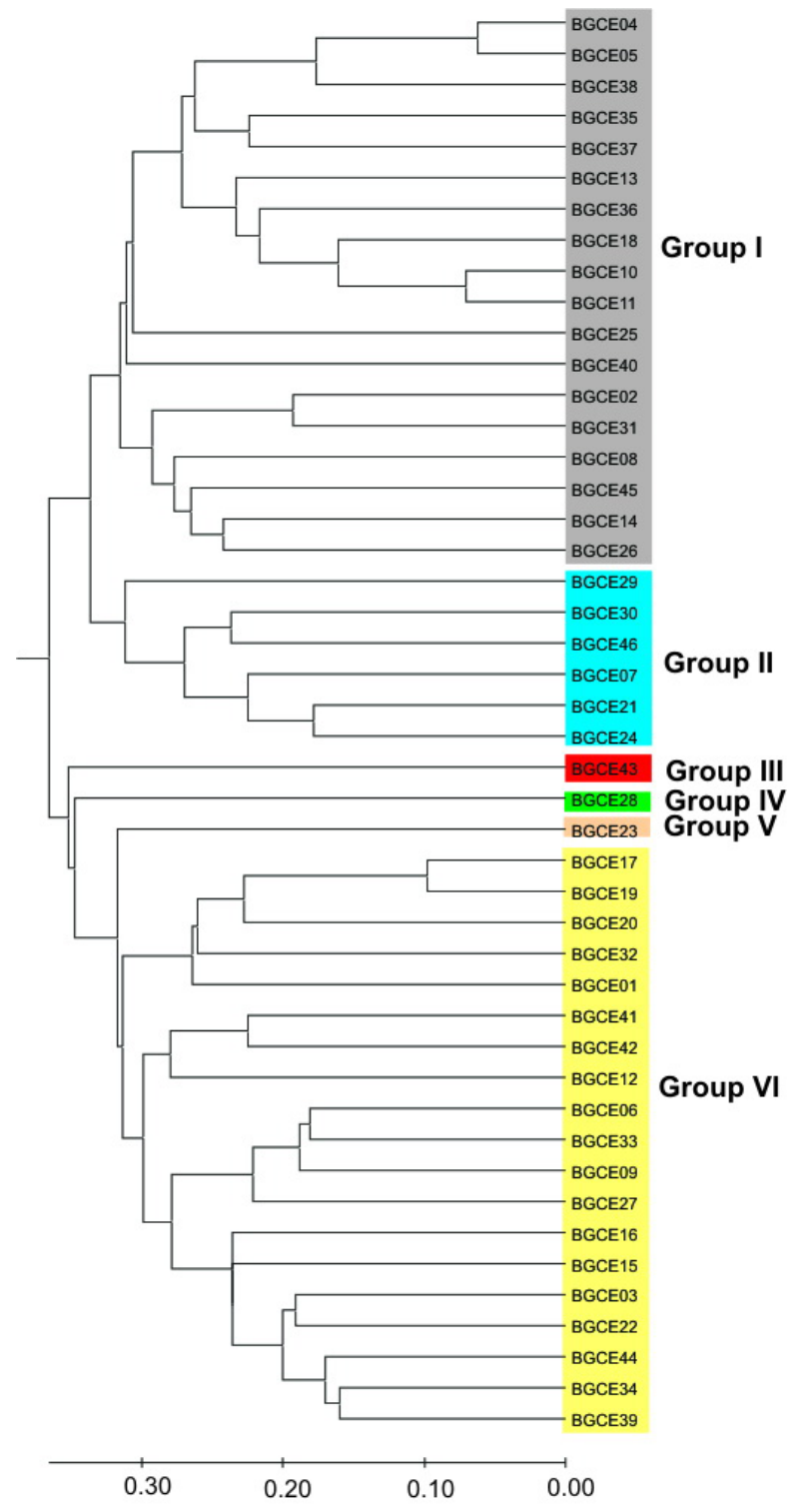

Figure 3. Dendrogram of genetic divergence among 46 accessions of elephant grass using the Jaccard coefficient based on the UPGMA algorithm from ISSR data. 


\section{Comparison between the RAPD and ISSR markers}

The estimate of the correlation between the genetic distances achieved by the RAPD and ISSR markers was 0.76 , with probability $\mathrm{P}<0.001$ by the Mantel test $(10,000$ permutations), indicating that there is a pattern of association between the results achieved by these two analytical procedures in the discrimination of the accessions. Concordant results between RAPD and ISSR have been observed in other articles (Behera et al., 2008; Muthusamy et al., 2008; Arif et al., 2009).

Babu et al. (2009), evaluating the variability among 30 accessions of elephant grass using RAPD and ISSR, verified low correlation $(\mathrm{r}=0.33)$ between the markers, indicating low correspondence between the polymorphisms brought by these techniques. However, when genotypes were evaluated by the UPGMA grouping method, the authors verified that both techniques were efficient in the geographical identification of the accessions.

The UPGMA grouping analysis allowed us to observe the association between the two markers evaluated here. Of the 17 accessions of Group I, gathered based on the RAPD markers, 12 were allocated in Group I (BGCE08, BGCE10, BGCE11, BGCE13, BGCE14, BGCE18, BGCE25, BGCE26, BGCE35, BGCE36, BGCE37, and BGCE45) and 4, in Group VI (BGCE17, BGCE19, BGCE20, and BGCE32) of the ISSR markers. Besides, in Group II of the RAPD marker, formed by 16 accessions, 14 accessions were allocated in Group VI (BGCE03, BGCE06, BGCE09, BGCE12, BGCE15, BGCE16, BGCE22, BGCE27, BGCE33, BGCE34, BGCE39, BGCE41, BGCE42, and BGCE44), based on the ISSR markers. This indicates that both techniques can provide consistent information for diversity analyses in accessions of elephant grass from different origins, with different edaphoclimatic adaptations.

\section{ACKNOWLEDGMENTS}

The authors thank FAPERJ (Fundação Carlos Chagas Filho de Amparo à Pesquisa do Estado do Rio de Janeiro), Brazil, for financial support for this study.

\section{REFERENCES}

Anderson WF, Dien BS, Brandon SK and Peterson JD (2008). Assessment of bermudagrass and bunch grasses as feedstock for conversion to ethanol. Appl. Biochem. Biotechnol. 145: 13-21.

Arif M, Zaidi NW, Singh YP, Haq QMR, et al. (2009). A comparative analysis of ISSR and RAPD markers for study of genetic diversity in shisham (Dalbergia sissoo). Plant Mol. Biol. Rep. 27: 488-495.

Arif IA, Bakir MA, Khan HA, Al Farhan AH, et al. (2010). A brief review of molecular techniques to assess plant diversity. Int. J. Mol. Sci. 11: 2079-2096.

Babu C, Sundaramoorthi J, Vijayakumar G and Ram SG (2009). Analysis of genetic diversity in napier grass (Pennisetum purpureum Schum) as detected by RAPD and ISSR markers. J. Plant Biochem. Biotechn. 18: 123-133.

Behera TK, Singh AK and Staub JE (2008). Comparative analysis of genetic diversity in Indian bitter gourd (Momordica charantia L.) using RAPD and ISSR markers for developing crop improvement strategies. Sci. Hortic. 115: 209-217.

Bhandari AP, Sukanya DH and Ramesh CR (2006). Application of isozyme data in fingerprinting napiergrass (Pennisetum purpureum Schum.) for germplasm management. Genet. Resour. Crop. Evol. 53: 253-264.

Daher RF, Moraes CF, Pereira AV, Cruz CD, et al. (1997a). Diversidade morfológica e isozimática em capim-elefante (Pennisetum purpureum Schum.). Rev. Bras. Zootec. 26: 255-264.

Daher RF, Moraes CF, Cruz CD, Pereira AV, et al. (1997b). Seleção de caracteres morfológicos discriminantes em capimelefante (Pennisetum purpureum Schum.). Rev. Bras. Zootec. 26: 265-270.

Daher RF, Pereira MG, Pereira AV and Amaral Júnior AT (2002). Genetic divergence among Elephantgrass cultivars 
accessed by RAPD markers in composit samples. Sci. Agric. 59: 623-627.

Gepts P (2006). Plant genetic resources conservation and utilization. Crop Sci. 46: 2278-2292.

Gonçalves LS, Rodrigues R, Amaral AT Jr, Karasawa M, et al. (2008). Comparison of multivariate statistical algorithms to cluster tomato heirloom accessions. Genet. Mol. Res. 7: 1289-1297.

Gonçalves LS, Rodrigues R, do Amaral Junior AT, Karasawa M, et al. (2009). Heirloom tomato gene bank: assessing genetic divergence based on morphological, agronomic and molecular data using a Ward-modified location model. Genet. Mol. Res. 8: 364-374.

Harris K, Anderson W and Malik R (2009). Genetic relationships among napiergrass (Pennisetum purpureum Schum.) nursery accessions using AFLP markers. Plant Genet. Resour. 8: 63-70.

Jakob K, Zhou F and Paterson AH (2009). Genetic improvement of C4 grasses as cellulosic biofuel feedstocks. In Vitro Cell Dev. Biol. Plant 45: 291-305.

Leal AA, Mangolin CA, do Amaral ATJ, Goncalves LS, et al. (2010). Efficiency of RAPD versus SSR markers for determining genetic diversity among popcorn lines. Genet. Mol. Res. 9: 9-18.

Lee MK, Tsai WT, Tsai YL and Lin SH (2010). Pyrolysis of napier grass in an induction-heating reactor. J. Anal. Appl. Pyr. 88: 110-116.

Lowe AJ, Thorpe W, Teale A and Hanson J (2003). Characterization of germplasm accessions of Napier grass (Pennisetum purpureum and P. purpereum x P. glaucum hybrids) and comparison with farm clones using RAPD. Genet. Resour. Crop Evol. 50: 121-132.

Mohammadi SA and Prasanna BM (2003). Analysis of genetic diversity in crop plants - salient statistical tools and considerations. Crop Sci. 43: 1235-1248.

Morais RF, Souza BJ, Leite JM, Soares LHB, et al. (2009). Elephant grass genotypes for bioenergy production by direct biomass combustion. Pesq. Agropec. Bras. 44: 133-140.

Muthusamy S, Kanagarajan S and Ponnusamy S (2008). Efficiency of RAPD and ISSR markers system in accessing genetic variation of rice bean (Vigna umbellate) landraces. Electron. J. Biotech. 11: 1-10.

Oliveira EC, Amaral Junior AT, Goncalves LS, Pena GF, et al. (2010). Optimizing the efficiency of the touchdown technique for detecting inter-simple sequence repeat markers in corn (Zea mays). Genet. Mol. Res. 9: 835-842.

Passos LP, Machado MA, Vidigal MC and Campos AL (2005). Molecular characterization of elephantgrass accessions through RAPD markers. Ciênc. Agro. . 29: 568-574.

Pereira AV, Machado MA, Campos AL, Ledo FJS, et al. (2008). Diversidade genética entre acessos de capim-elefante obtida com marcadores moleculares. Rev. Bras. Zootec. 37: 1216-1221.

Sanderson MA, Reed RL, McLaughlin SB, Wullschleger SD, et al. (1996). Switchgrass as a sustainable bioenergy crop. Bioresour. Technol. 56: 83-93.

Shimoya A, Cruz CD, Ferreira RP, Pereira AV, et al. (2002). Divergência genética entre acessos de um banco de germoplasma de capim-elefante. Pesq. Agropec. Bras. 37: 971-980.

Smith RL, Schweder ME, Chowdhury MKU, Seib JC, et al. (1993). Development and application of RFLP and RAPD DNA markers in genetic improvement Pennisetum for biomass and forage production. Biomass Bioenergy 5: 51-62.

Strezov V, Evans TJ and Hayman C (2008). Thermal conversion of elephant grass (Pennisetum purpureum Schum) to bio-gas, bio-oil and charcoal. Bioresour. Technol. 99: 8394-8399.

Struwig M, Mienie CMS, Van den Berg J, Mucina L, et al. (2009). AFLPs are incompatible with RAPD and morphological data in Pennisetum purpureum (Napier grass). Biochem. Syst. Ecol. 37: 645-652.

Sudré CP, Goncalves LS, Rodrigues R, do Amaral Junior AT, et al. (2010). Genetic variability in domesticated Capsicum spp as assessed by morphological and agronomic data in mixed statistical analysis. Genet. Mol. Res. 9: 283-294.

Williams JG, Kubelik AR, Livak KJ, Rafalski JA, et al. (1990). DNA polymorphisms amplified by arbitrary primers are useful as genetic markers. Nucleic Acids Res. 18: 6531-6535. 